\title{
SE DEUS FOSSE JAGUAR: CANIBALISMO E CRISTIANISMO ENTRE OS GUARANI (SÉCULOS XVI-XX)*
}

Carlos Fausto

Perecer é não ser mais nada daquilo que se foi; ser mudado é ser de outro modo (Tertuliano, De ressurectione mortuorum, cap. LV)

Todo vir-a-ser é o perecer de algo e todo perecer é o vir-a-ser de outra coisa (Aristóteles, Da Geração e Corrupção — livro I, cap. 3)

Ore kurusu ñe'ëngatu ra'y, kurusu ñe'ëngatu rajy, ore ára jeguaka ra'y "Nós [excl.] somos filhos e filhas da cruz da boa palavra, somos filhos do diadema do tempo" - dizem de si mesmos os Kaiová, um subgrupo guarani do Brasil e do Paraguai ${ }^{1}$. Kaiová é uma corruptela de Kaaguá, "habitantes da mata", termo genérico pelo qual ficaram conhecidas as populações guarani que se teriam mantido irredutíveis ao sistema colonial. Kurusu, por sua vez, é a indigenização de cruz, um conceito extremamente produtivo na cosmologia atual dos Kaiová: ela é o sustentáculo da Terra que se desarmará no cataclisma final, mas também é uma pessoa, pois do morto se diz que é uma ex-cruz (kurusu kué), além de ser um instrumento do pajé, que a traz em uma das mãos, enquanto na outra faz soar o maracá (Chamorro 1995:61-62).

Como devemos entender a afirmação dos Kaiová de que são os filhos da "cruz da boa palavra", aqueles que brotaram da "base espumante da cruz" (Chamorro 1995:60)? Qual o estatuto dessa autodefinição e como interpretá-la? Trata-se de um arremedo de cristianismo mal compreendido ou de um mero verniz sob o qual se esconde uma verdadeira religião indígena? Essas são algumas das perguntas que assombraram a etnologia sobre os Guarani no século XX, e que já atormentavam os missionários nos primeiros séculos da colonização, para os quais a desconversão e o criptopaganismo eram problemas tão reais quanto ensinar os mistérios da fé. 
A imagem mais difundida das missões jesuíticas do Paraguai, contudo, não é essa. Ao contrário, nela, os Guarani aparecem como aceitando docilmente a catequese, graças à virtude dos padres ou a uma espécie de pré-adaptação de sua cultura ao cristianismo. Já no século XVI, falava-se em uma maior propensão dos Guarani à conversão (quando comparados aos Tupi), uma idéia que foi reforçada pela historiografia das missões seiscentistas e setecentistas que enalteceriam seu suposto sucesso religioso ${ }^{2}$. A antropologia moderna veio ao encontro dessa imagem: "Na superfície da terra", escrevia Egon Schaden nos anos 1950, "não há, por certo, povo ou tribo a que melhor se aplique do que ao Guarani a palavra evangélica: O meu reino não é deste mundo. Toda a vida mental do Guarani converge para o Além" (1954a:248).

A antropologia, porém, não fez dessa inclinação para o Além um motivo de conversão, mas sim de resistência, tradição e memória. A imagem que ela construiu dos Guarani no século XX, embora não-monolítica, supôs tal continuidade em matéria de religião, que as cosmologias contemporâneas aparecem quase como uma sobrevivência proto-histórica intocada pelo processo colonial. Temos assim, de um lado, o milagre da conversão, de outro, a tenaz resistência da crença como fundamento de uma identidade impermeável à mudança e à alteridade.

Entre esses dois pólos - descontinuidade e continuidade puras - existe um terreno de dúvida e de inquietude, mais produtivo do que o das imagens extremas e pacificadas. Nas últimas décadas, novas abordagens sobre a história e a antropologia das missões religiosas na América do Sul indígena permitiram recuperar a complexidade do fenômeno e relativizar o mito das reduções jesuíticas ${ }^{3}$. Não se fez, porém, a crítica similar no que toca à etnologia dos Guarani, de tal modo que mesmo os estudos históricos continuam a repetir equívocos bem estabelecidos e interpretações questionáveis, como se fossem dados empíricos primários ${ }^{4}$. Este texto visa iniciar um trabalho crítico, explorando - e não denegando - a noção de transformação, tomada como processo que se desenrola no tempo (uma história), como produção de um espaço topológico (uma estrutura) e como categoria nativa. Trata-se de desestabilizar visões tradicionais consolidadas na literatura para abrir campo a novas interpretações. Os limites do texto são dados, pois, por esse objetivo, de tal modo que me restrinjo aos "Guarani de papel; esto es en papel" (Meliá 2004:176)

Em trabalhos anteriores, procurei lidar com algumas dicotomias clássicas da antropologia - estrutura e ação, mito e história, continuidade e mudança — propondo análises que, se recorrem a estes pares opostos, alteram a relação entre eles. Assim, por exemplo, na noção de "agência mítica", mantive a distinção entre mito e história, mas rejeitei o contraste em termos de passividade 
e atividade (Fausto 2002a). Do mesmo modo, ao enfatizar as condições pragmáticas de atualização de certas crenças em uma situação histórica particular, insisti sobre sua existência na longue durée (Fausto 2002b). Agora, quero enfrentar estas questões em um quadro temporal mais amplo, tomando como objeto a chamada "religião" guarani, sobre a qual temos informações desde o século XVI. Meu intuito é sugerir como e em que direções ela se transformou, recriando-se como a "religião" guarani atual. Minha hipótese de trabalho é a de que o contato com o cristianismo missionário e a experiência colonial conduziram a uma crescente negação do canibalismo como fundamento do poder xamânico e da reprodução social, processo ao qual podemos dar o nome de "desjaguarificação". Sugerirei ainda que esse esquecimento do canibalismo abriu espaço para uma outra idéia-chave, a do amor.

Para desenvolver esta hipótese, começarei por um breve apanhado da situação colonial dos Guarani no Paraguai. Em seguida, apresentarei a imagem que deles construiu a etnologia, a qual será criticada por meio de dois procedimentos: um retorno à história das missões e uma análise estrutural das transformações evidenciadas pelas cosmologias atuais. Encerrarei com algumas sugestões comparativas sobre outros processos de desjaguarificação na Amazônia.

\section{Os Guarani na primeira história colonial}

A numerosa população que ocupava o litoral atlântico da América do Sul e a bacia do Prata no século XVI ficou conhecida como Tupi-Guarani, termo que reúne as designações dos dois principais blocos que a constituíam: os Tupi, que viviam ao norte de São Paulo; os Guarani, que se estendiam ao sul até a Lagoa dos Patos e, principalmente, ao longo dos rios Paraná, Paraguai e Uruguai. É difícil precisar quando essa grande divisão consolidou-se na literatura, mas é certo que começou a ser forjada pelos próprios agentes coloniais $^{6}$. Nos séculos XVI e XVII, no entanto, predominaram as designações locais, tais como Tamoio, Tupinambá, Tupiniquim, Tabajara, para os Tupi; e Carijó, Itatim, Tapé, Guarambaré, para os Guarani. Foi, no entanto, este último termo, derivado da palavra nativa para "guerra" (Montoya 1876), que acabou se fixando como designação geral.

Os primeiros contatos dos Guarani com os europeus datam do início do século XVI. A informação mais antiga é o relato do capitão normando Paulmier de Gonneville, que aportou na costa de Santa Catarina em 1503, e lá permaneceu por seis meses. Até meados do século, no entanto, as terras guarani e a bacia do Prata foram consideradas apenas uma via de 
passagem para se atingir, desde o Leste, a cordilheira dos Andes e suas riquezas minerais. Em 1524, o português Aleixo Garcia, guiado e escoltado pelos Guarani, conseguiu chegar ao Império Inca partindo do litoral sul do Brasil. A notícia da expedição levou os espanhóis a explorarem o Prata, fundando Buenos Aires em 1536 e Asunción no ano seguinte.

A colonização da região, porém, só ganhou impulso quando se tornou claro que as minas andinas já haviam sido monopolizadas pelos conquistadores do Peru. Assim, em 1556, começa a ser implantado o sistema de encomiendas no Paraguai, a fim de organizar a utilização da mão-deobra indígena em torno de Asunción. Esse sistema, que regulamentava os serviços prestados pelos índios aos conquistadores, teria representado uma ruptura nas relações menos normatizadas e pautadas por mecanismos de aliança e parentesco, que até então vigia entre os poucos espanhóis e os muitos Guarani (Necker 1979). A implantação das encomiendas talvez responda, assim, pela intensificação das rebeliões indígenas, que já haviam sido violentamente reprimidas desde, pelo menos, o início dos anos $1540^{7}$.

A partir da década de 1570, essas rebeliões passaram a expressar-se em uma linguagem xamânica e/ou messiânica. Os primeiros registros desses movimentos coincidem com o início da ação missionária no Paraguai, empresa levada a cabo pelos franciscanos com o apoio do governador Hernando Arias de Saavedra, que via no sistema reducional a solução para dois problemas: limitar o poder dos encomenderos e pacificar os Guarani ${ }^{8}$. Assim, conjugando-se a ação militar governamental à ação catequética franciscana - em um contexto de brutal queda demográfica causada pelas epidemias e pelas guerras - pavimentou-se a via para a instalação das missões jesuíticas. Estas surgiram na primeira década do século XVII e logo se tornaram hegemônicas no contexto missionário paraguaio, embora tenham sido duramente atingidas, entre 1628 e 1641, pelos ataques dos bandeirantes paulistas. Vários núcleos reducionais foram, então, destruídos e outros abandonados.

Na década de 1640, houve uma reorganização econômica, espacial e militar do Paraguai, o que conduziu a uma estabilização relativa do sistema reducional (Monteiro 1992:493). Não se deve pensar que tal estabilização levou ao isolamento das missões. Elas se mantiveram articuladas - de maneira contraditória, é verdade - tanto ao sistema econômico e político colonial, quanto aos índios irredutíveis, os chamados monteses ou ca'águara ("habitantes da mata"). Estas designações encobriam, na verdade, uma diversidade de situações. Entre os monteses, contavam-se refugiados das revoltas, fugitivos do sistema de encomiendas, ex-neófitos das missões, bem como pessoas e grupos que não tinham qualquer experiência de convívio 
com não-índios. A situação colonial, apesar das restrições impostas pelo sistema de encomiendas e pelo regime reducional, era muito mais lábil do que se costuma imaginar, inclusive no que diz respeito à circulação de pessoas e coisas. Ademais, a história das missões foi sempre marcada por grandes flutuações demográficas, seja pelos movimentos silenciosos e constantes de pessoas e famílias indígenas, seja pelas migrações intensas e crises epidêmicas que ocorreram em vários momentos desde o início da missionarização .

As crises demográficas e a concentração da população nos pueblos provinciais e nas reduções missionárias provavelmente criaram áreas inabitadas, que garantiam certo isolamento aos monteses. Ao mesmo tempo, a expansão da coleta de erva-mate conduziu criollos e índios missionados a ingressarem em novas áreas em busca de ervais e, assim, a contatar populações indígenas supostamente isoladas. A diversidade da experiência histórica desses monteses pode ser entrevista nos relatos missionários. No século XVIII, por exemplo, os padres estabeleceram contato com os Itatim "que por 'notícias' conheciam os 'crucíferos' (missionários jesuítas), e haviam adotado o 'kurusú potý' [a flor da cruz]" (Susnik 1980:188), um indício de relações pretéritas com o universo religioso colonial. No mesmo período, contataram os índios de Mbaeverá que, supostamente, não apresentavam qualquer sinal de influência cristã, vivendo como seus antepassados e seguindo seus xamãs os quais, como diria o Pe. Dobrizhoffer, "arrogam-se pleno poder [...] de transformarem-se em jaguares" (1970 [1784]:63).

Para resumir nossa história, digamos que, a partir de então, assistiríamos, de um lado, a uma crescente distinção sociocultural entre os Guarani monteses e os demais Guarani e, de outro, a uma progressiva indistintibilidade entre os Guarani dos pueblos provinciais e os das missões, e de ambos em relação à população mestiça pobre. Esse processo foi reforçado pela expulsão dos jesuítas na segunda metade do século XVIII, o que levaria ao definhamento do sistema reducional e à crescente integração da população nativa na economia e na sociedade envolventes ${ }^{10}$. Dentre os resultados desse processo contam-se a constituição de uma população rural, que se tornará parte de Estados nacionais independentes no século XIX, e de uma população indígena reconhecida como Guarani, que será estudada pela antropologia no século XX.

\section{Os Guarani e sua etnologia}

A primeira etnografia dos Guarani foi publicada na Alemanha, em 1914, por Curt Nimuendaju e versa sobre grupos que se encontravam então no 
estado de São Paulo, mas eram originários do Mato Grosso do Sul. Essa população teria começado a migrar para Leste a partir do início do século XIX, motivada por uma esperança "messiânica": a de atingir a Ywy marãey, expressão que Nimuendaju traduziu como "Terra sem Mal" e que assim ficou consagrada na literatura posterior ${ }^{11}$. As migrações eram dirigidas por xamãs que anunciavam o fim iminente do mundo e conclamavam seus adeptos a segui-los, em meio a cantos e danças, para uma terra de promissão, sem doença ou morte, a qual acreditavam situar-se além-mar ${ }^{12}$.

No início do século XX, os Apapocuva ("Gente do Arco Longo") autodesignação do principal grupo estudado por Nimuendaju - estavam em contato permanente com a sociedade nacional. Haviam adotado uma série de elementos não-indígenas como roupas, cruzes, nomes cristãos, mas mantinham, segundo o autor, um universo mítico-religioso tipicamente indígena, fundado em uma cataclismologia. A visão de mundo apapocuva não trairia, segundo Nimuendaju, quaisquer "tendências cristãs", pois os principais motivos de sua religião seriam "arqui-indígenas". O que lhes seria específico seriam a elaboração teórica e a produtividade prática desses motivos, que teriam resultado do sofrimento a eles imposto nos séculos precedentes (Nimuendaju 1987:131). Daí a célebre comparação com o criptojudaísmo: assim como Heine se fizera cristão para ser judeu em paz, os Apapocuva teriam adotado signos exteriores do cristianismo para continuarem a ser intimamente guarani (Nimuendaju 1987:27).

O texto de Nimuendaju delineou as grandes questões da etnologia guarani posterior, em particular, o problema da autenticidade ou não da religião contemporânea. Nos anos 1950, o tema reapareceria nas mãos de Egon Schaden, também alemão de origem, e tributário dos estudos de aculturação. Preocupado em mapear os traços não-tradicionais presentes na vida indígena, ele insistiria que a religião guarani sofrera profundas influências cristãs, mas que a assimilação de novos elementos não teria obliterado e sim acentuado "ao extremo certos valores centrais da própria doutrina tribal primitiva, reinterpretando ensinamentos do Cristianismo segundo o espírito desta" (1964:105).

Esse esboço de uma noção de indigenização da tradição permaneceu inexplorado pela etnologia guarani das décadas de 1960 e 1970, na qual predominam as noções de preservação e identidade ${ }^{13}$. O livro-chave nesse momento é Ayvu Rapyta: textos míticos de los Mbyá-Guarani del Guairá, publicado por León Cadogan, em 1959. Nele, os Mbyá do Guaíra são apresentados como uma população isolada, que teria conservado, como escreve Schaden no prefácio do livro, "as suas tradições na original pureza, i.e., sem modificação por influência cristã, quer do tempo das missões 
jesuíticas, quer da época mais recente" (1959:5). Dentre os textos coletados e traduzidos por Cadogan, será o primeiro conjunto, denominado $\tilde{N} e^{\prime} e \ddot{~}$ Porã Tenonde ("As primeiras belas palavras"), que reterá a atenção da maioria dos autores posteriores.

Apresentadas como tradição secreta e esotérica à qual o autor só teve acesso após anos de relações e serviços prestados aos Mbyá, as "Primeiras belas palavras" descrevem a origem da divindade suprema e do fundamento da linguagem humana (justamente Ayvu Rapyta), a criação da primeira terra, a maneira pela qual a palavra-alma se encarna (ou melhor, se assenta) e o dilúvio universal que destruiu a terra primitiva. O dilúvio encerra, na expressão de Cadogan (1959:68-70), a primeira parte "dos anais religiosos dos Mbya", seus "capítulos mais sagrados"; o que se segue seriam lendas semelhantes aos mitos de outros povos indígenas.

Essa passagem da religião mística à mitologia primitiva leva Cadogan a se perguntar se tal contraste denunciaria enxerto ou sincretismo: "os profundos conceitos religiosos, a linguagem elevada [...] dos capítulos que constituem a primeira parte [...] bem poderiam ter sido extraídas dos anais de uma raça muito mais culta que a mbyá" (1959:70). Ele refuta a hipótese, afirmando a autenticidade não corrompida das "Primeiras belas palavras", pois estas teriam permanecido desconhecidas dos brancos e ao abrigo da influência missionária. Passamos, assim, do cripto-paganismo de Nimuendaju, visto como um mecanismo de defesa contra a sociedade envolvente, para uma religião secreta transmitida secular e imaculadamente no interior da floresta.

É essa a passagem que Pierre Clastres terminará de realizar, ao publicar em 1974 vários dos textos de Cadogan, acompanhados por outros que ele mesmo coletara e por alguns de Nimuendaju. Na introdução, como lhe era característico, P. Clastres reúne em uma só formulação pólos opostos do pensamento ocidental para solapar sua estrutura. Sucedemse aí imagens de pureza, mas não de primitividade. Para o autor, as "Belas palavras" da religião guarani que ainda hoje "ecoam nos lugares mais secretos da floresta [...] ao abrigo de toda mácula" (1974:7-8) guardam uma profundidade metafísica comparável a das grandes tradições do pensamento reflexivo. Elas exprimem um desejo de sobre-humanidade e imortalidade, pensam o mundo e o infortúnio, são o ápice de um universo religioso que é "a substância da sociedade guarani", "fonte e fim de sua força de viver" (1974:8).

Essa adesão profunda dos Guarani à sua religião era, para P. Clastres, sobretudo um fato político: por um lado, era um signo de resistência ao processo etnocidário da Conquista; por outro, o resultado de uma crise 
política autóctone, anterior à própria colonização. Sua hipótese supunha um crescimento do poder dos chefes tupi-guarani e a emergência de cacicados no final do século $\mathrm{XV}$, que teriam conduzido a movimentos religiosos reativos, animados pelas palavras proféticas dos grandes xamãs. Estes conclamavam os índios a tudo abandonarem e a partirem em busca da "Terra sem Mal", catalisando o desejo de uma sociedade que buscava permanecer idêntica a si mesma e impedir a eclosão de uma divisão política irreversível $^{14}$. A chegada dos europeus à América, contudo, não lhe seria indiferente. A violência colonial e a ocupação dos territórios teriam inviabilizado as migrações de grandes proporções e, assim, "fechado [...] pelo lado da práxis, o desejo de eternidade dos Guarani buscou seu encaminhamento no aprofundamento da Palavra, ele extravasou pelo lado do logos" (1974:10).

Com essa hipótese, P. Clastres respondia à questão que incomodava Cadogan: qual a origem dessas Belas Palavras que explicam a geração de Nosso Pai Primeiro e Último (Ñande Ru Pa-pa Tenonde), que se autoconcebera nas trevas primordiais e que de sua sabedoria engendrara a linguagem humana e o amor, antes mesmo de criar a primeira terra, e que esta fizera para depois destruí-la, comandando a outra divindade para reconstruí-la, mas agora repleta de infelicidade? Sua origem, enfim, seria um pli sur soi même da religião guarani, que teria levado à substituição da mitologia pela metafísica.

Em resumo, o problema da conversão que tanto afligia os jesuítas no século XVII transformou-se no século XX em um problema antropológico de identidade e contaminação. Se, por um lado, os estudos etnológicos mostraram com acerto que a "religião" guarani no século XX não partilhava de uma série de dicotomias características da soteriologia cristã, por outro, tenderam a depurar e a denegar qualquer transformação em nome de um núcleo duro e puro da religiosidade guarani ${ }^{15}$. Esse essencialismo que Nimuendaju já professava foi reforçado pela "descoberta" dos Mbyá do Guaíra, apresentados como representantes derradeiros de uma guaranicidade intocada.

\section{Histórias de inconversão}

A concepção de cultura e tradição, que subjaz às idéias de pureza e autenticidade da "religião" guarani, parece-me difícil de sustentar à luz da etnologia amazônica contemporânea, em particular aquela de inspiração estruturalista que se ergueu sobre uma definição anti-identitária de 
sociedade e cosmologia indígenas, e colocou em primeiro plano de análise a alteridade. Como conciliar essa perspectiva, que se mostrou etnograficamente produtiva, com a caracterização dos Guarani como fechados em si mesmos, resistentes e impermeáveis à alteridade dos brancos?

Essa impermeabilidade contrasta fortemente com o que lemos nas crônicas quinhentistas e seiscentistas. Aí se encontram diversas passagens sobre o complexo jogo de apropriação e reelaboração de signos e idéias cristãos por caciques e xamãs guarani. Em 1594, o padre Alonso Barzana já nos dava indicações disso ao descrever movimentos de rebeldia dirigidos por índios que se autoproclamavam Papa ou Jesus Cristo (apud Meliá 1986:39). Os mesmo temas encontram-se no poema de Barco de Centenera (1602), que conta o levante de Guarambaré, comandado por Overá em 1579, líder messiânico que se dizia filho de Deus, nascido de uma virgem. O poema nos fala de um índio batizado, que vivera em um povoado submetido aos encomenderos e que de lá saíra, predicando terra adentro, prometendo aos índios a liberdade, e mandando "que cantasen y bailasen, de suerte que outra cosa no hacían". Dentre os cantos, o mais comum seria: "Obera, obera, obera, pay tupa, yandabe, hiye, hiye, hiye", que se traduziu como "resplendor, resplendor, resplendor do padre, também Deus para nós, roguemos, roguemos, roguemos" (Meliá 1986:36, 113) ${ }^{16}$.

As reduções jesuíticas foram palco de várias situações de confronto entre padres e índios, em que estes recorriam às armas daqueles e viceversa $^{17}$. No caso dos sacerdotes, esse uso era por vezes mera artimanha para dobrar um "mago", um "feiticeiro". Mas em geral tratava-se de convergência, ainda que equívoca, dos respectivos imaginários sobre o sobrenatural e sobre a intervenção de poderes extra-humanos no mundo vivido humano. Chefes e xamãs indígenas, por sua vez, eram mais vorazes em consumir rotinas rituais e objetos litúrgicos, sendo acusados pelos jesuítas de "fingirem-se de sacerdotes". Montoya narra como o cacique Miguel Artiguaye, "adornando-se com uma capinha de plumas vistosas e outros enfeites, simulava estar dizendo a missa. Punha sobre uma mesa algumas toalhas e em cima delas uma torta de mandioca e um vaso, mais que pintado, com vinho de milho e, falando entre os dentes, fazia muitas cerimônias [...]" (1985 [1639]:57).

Os confrontos religiosos podiam resolver-se por meio de ameaças e de derrisão, mas algumas vezes escalavam em violência aberta. Em 1628, por exemplo, após ter admitido os missionários em suas terras, o cacique e xamã guarani Neçu ordenou que fossem mortos. Consumado o assassinato, Neçu "para mostrar-se sacerdote, conquanto falso, revestiu-se dos paramentos litúrgicos do padre e com eles apresentou-se ao povo. E fez trazer 
em sua presença as crianças, nas quais tratou de apagar com cerimônias bárbaras o caráter indelével que elas, pelo batismo, tinham impresso em suas almas" (Montoya 1985 [1639]:201-202). O "desbatizar" era um ato a que os Guarani parecem ter emprestado tanta importância quanto os padres colocavam no batismo. Raspavam as línguas das crianças que "haviam saboreado o sal do espírito sapiencial", suas costas e peitos para "borrar os santos óleos", ou invertiam o ritual lavando-as dos pés às cabeças.

O uso e o abuso do imaginário reducional nessas circunstâncias indicam que, do ponto de vista indígena, o que estava em jogo não era um conflito entre duas "religiões", duas ortodoxias ou credos mutuamente exclusivos (ver Greer 2003:4) ${ }^{18}$. Isto porque, de um lado, como mostrou Viveiros de Castro (1992a), o estilo de religiosidade tupi-guarani era avesso à ortodoxia. Eles não tinham fé ou crença em seus xamãs no mesmo sentido em que os missionários acreditavam em Deus ou nas Escrituras. De outro lado, o sistema reducional não era composto por dois sistemas de mundo estanques, divididos por uma fronteira impermeável, mas conformavam uma rede social em que se traficavam não apenas bens, mas signos continuamente reinterpretados. Como indica Griffiths (1999:9), os missionários não podiam controlar os significados produzidos na relação com os índios; suas idéias, uma vez postas em circulação, ganhavam autonomia em relação à origem. Esse processo, na verdade, começava já com a adaptação das categorias nativas para a tradução dos catecismos na língua indígena, uma tarefa que contava com o auxílio de informantes bilíngües, e prosseguia a cada evento ritual.

O problema central para os índios não era, pois, como retornar a uma identidade perdida, mas sim como apropriar-se dos poderes extraordinários que os europeus, e em particular os padres, pareciam possuir ${ }^{19}$. E aqui, a reelaboração de rituais, o uso de vestimentas sacerdotais e a posse de objetos litúrgicos não tinham um papel menos importante. Não eram simples paródias desrespeitosas do cristianismo ou uma artimanha do Diabo, como pensavam os jesuítas. Tampouco tratava-se de mera superfície que escondia na essência uma guaranicidade pura, como sugeriria séculos mais tarde Nimuendaju. Esses objetos e hábitos eram como as máscaras utilizadas nos rituais indígenas para tornar presente um espírito ou como as peles de jaguar com que os xamãs se transvestem em sonho para fazerem-se felinos (Fausto 2004; m.s.). Não se tratava de representação no sentido dramático, mas de transformação, de apropriação de capacidades, algo que os missionários reforçavam pois, eles mesmos, acreditavam no poder místico do hábito para além de sua função institucional ${ }^{20}$. Aqui, vale literalmente o dito de que o hábito faz o monge. 
A apropriação do imaginário e do poder dos missionários raramente passou pela devoração literal, que era uma das operações clássicas de captura de identidades e subjetividades entre os Tupi-Guarani. Os jesuítas não foram alvo privilegiado da antropofagia. Ao contrário, parece ter-se evitado comê-los, reservando esse destino aos índios neófitos (ver Montoya 1985:83, 165-166, 235). No início do século XVII, os mártires da Companhia de Jesus assassinados pelos Guarani tiveram seu corpo despedaçado e queimado, como se fosse preciso nadificá-los para evitar uma vingança xamânica ou para negar-lhes a imortalidade de que tanto falavam. Há uma notável semelhança entre o modo pelo qual os padres eram mortos e a maneira pela qual, nos mitos indígenas, procura-se dar cabo de um demiurgo ou xamã $\tilde{a}^{21}$. Nestas narrativas nada pode destruir o corpo dos xamãs primordiais e esse é o signo de seu poder e de sua imortalidade ${ }^{22}$.

As descrições de Montoya (1985:202-203; 234-235) sobre o diálogo entre padres e matadores que precedia sua mise à mort, sugerem que a imortalidade era um dos pontos em disputa, mesmo se as concepções sobre esta fossem diversas. Frente ao destino fatal, o missionário afirmava que podiam matar-lhe o corpo, mas não a alma, pois esta é imortal. Menos preocupados com a alma do que com o corpo (ou talvez por não suporem tal dicotomia), os Guarani tratavam de despedaçar a vítima antes de queimá-la: separavam seus membros, cortavam-na ao meio, retiravamlhe o coração. Assim o fizeram com o padre Cristovão de Mendoza, cujo coração "que ardia em amor por eles" foi flechado por "feiticeiros obstinados" que diziam: "Vejamos se sua alma morre agora" (Montoya 1985: 234-235).

\section{Se deus fosse jaguar}

Não sabemos se a alma dos padres era ou não imorredoura. Mas teriam suas palavras e atos deixado marcas no discurso religioso guarani? Vimos que a maioria dos etnólogos respondeu a essa questão por uma simples negação ou recorreu à dicotomia essência e aparência para afirmar que a religião (cultura) guarani permaneceu idêntica a si mesma. Concebido como um conjunto de crenças firmemente interiorizadas e zelosamente protegidas, esse núcleo essencial constituiria o eixo da existência e identidade guarani, aquilo que os impediria de sucumbir a um estado amorfo de indiferenciação sincrética. Mas por que é preciso negar a transformação para afirmar a identidade de uma cultura e, portanto, sua distintividade? Por que é preciso fundir o problema da individuação com o problema do 
Mesmo, do idêntico? E, enfim, "o que significa permanecer o mesmo ao longo do tempo?" (Ricouer 2000:98). Do ponto de vista estrutural, permanecer no tempo e no espaço é transformar-se (sendo que o problema torna-se então saber qual o limite a partir do qual uma estrutura não é mais ela mesma). Do ponto de vista fenomenológico, a questão é como é possível ser outro e continuar a pensar-se como si mesmo? Deixemos em suspenso a última pergunta e comecemos a enfrentar o problema da transformação pelo plano estrutural.

Aqui chegamos finalmente ao que chamei de "desjaguarificação": uma negação do canibalismo como condição geral do cosmos e mecanismo de reprodução social. A cosmologia guarani contemporânea caracterizase por uma disjunção de figuras estreitamente articuladas em outros sistemas tupi-guarani: sangue e tabaco, guerreiro e xamã passam a opor-se diametralmente. Essa disjunção atravessa vários domínios do pensamento guarani, a começar pela concepção da pessoa, onde encontramos uma dicotomia entre dois princípios anímicos que, simplificando, podem ser caracterizados como uma alma "divina" e outra, "animal" ${ }^{23}$. A primeira é normalmente chamada de Ayvu ou Ñëë e traduzida por alma-palavra. Sua origem é divina e cabe ao xamã determinar sua fonte durante a cerimônia de nominação. Por meio do canto, ele indaga das várias divindades a procedência da alma e o seu nome (Nimuendaju 1987:30).

A essa alma pré-constituída celeste vem se agregar outra, denominada normalmente acygua, vocábulo que, segundo Nimuendaju (1987:33), é um particípio de acy, cujo significado é "dor" e "vivaz, violento, vigoroso"; o acyguá é, portanto, ao mesmo tempo, o que dói e o que tem vigor. Há certa ambigüidade na literatura quanto à caracterização dessa alma: por vezes, ela aparece como uma alma-animal, regressiva, que responde pelas pulsões sexuais, o impulso violento e o desejo de comer carne; outras, como uma alma de um animal cujas qualidades determinam o caráter da pessoa, de tal modo que um acyguá de borboleta não oferece o mesmo perigo que o de um jaguar. No entanto, este último parece corresponder ao tipo-ideal que domina a simbologia do acyguá, e é o destino de todo ser humano que não se pauta pelas condutas religiosas e generosas.

A dicotomia de princípios anímicos expressa-se em duas figuras extremas da pessoa masculina guarani: de um lado, a daqueles que se deixam dominar pela alma animal e pelo desejo de comer carne crua, cuja sina é transformar-se em jaguar; de outro, a do asceta que busca em vida o estado de maturação-perfeição (aguyje), cujo destino é tornar-se imortal. Como mostra H. Clastres (1975:113-134), essa dicotomia possui uma correspondência ética e alimentar: o primeiro é o caçador egoísta que come os animais abatidos na floresta para não ter de dividi-los; o 
segundo é o caçador generoso que dá toda a caça para os parentes, pois se abstém de carne ${ }^{24}$. O vegetarianismo é uma condição essencial — junto com a dança e os cantos regados a cauim - para se juntar aos deuses: "devido a essa forma de vida", contaram os Apapocuva a Nimuendaju, "seus corpos [dos grandes xamãs] se fizeram leves: o acyguá [...] era subjugado, enquanto o ayvucué tomava o caminho de onde viera: durante as danças de pajelança, suas almas abandonavam a terra e retornavam a Ñandecy [Nossa Mãe], Ñanderyqueý [Nosso Irmão mais Velho] ou Tupã. Por vezes, encontrava-se seu corpo morto, por vezes, eles ascendiam em seu corpo vivo" (Nimuendaju 1987:62).

A mansidão, a generosidade, a ética alimentar antivenatória, os cantos que provêm das divindades, a participação nos rituais, tudo isso deve orientar a conduta do Guarani para que sua alma-palavra se imponha sobre sua alma-animal. Na morte, enfim, ocorre a disjunção definitiva entre esses dois componentes da pessoa. A ex-alma-palavra (ayvu-kwe) volta para o céu após vencer alguns obstáculos, enquanto o acyguá torna-se um temível espectro, o anguéry ${ }^{25}$. Essa dualidade póstuma encontra paralelo em vários grupos tupi-guarani da Amazônia, mas possui aqui uma permutação importante; a saber, o apagamento da função-canibal associada à morte e ao xamanismo.

Tomemos para fins comparativos o caso araweté em que temos também uma cosmologia verticalizada e uma ênfase na relação xamânica com as divindades. Os Araweté postulam a existência de uma só alma chamada $\ddot{i}$, que designa tanto o princípio vital como a sombra projetada pelo corpo. Na morte, ela se divide em dois componentes: uma projeção póstuma da sombra (o espectro, ta'o we) e um espírito (também chamado i) que vai para o céu. Esse espírito é, então, devorado e imortalizado pelos deuses, que são ditos "comedores de cru", isto é, jaguares. O xamanismo araweté faz justamente a mediação entre os humanos e esses deuses-jaguares (Viveiros de Castro 1992b:90; 201-214). Figura semelhante encontra-se entre os Asurini do Tocantins, no entanto, com um deslocamento interessante. Eles postulam uma única alma em vida chamada iunga, que é depositada pela divindade Mahira nas mulheres. Com a morte, ela se separa em um aspecto celeste e outro terrestre. O primeiro junta-se a Mahira em Tupana, o segundo torna-se um espectro chamado asonga, cognato do anhanga tupinambá, espírito canibal associado aos mortos. O espírito que vai para Tupana deixa de ter significação para os vivos, enquanto o asonga fica na Terra e torna-se um auxiliar dos sonhadores, tendo papel relevante no encontro dos pajés com o jaguar celeste, fonte última do poder xamânico (Andrade 1992:217-249). 
Em ambos os casos, apesar das permutações, a função-jaguar está associada positivamente ao xamanismo. E é assim na maioria dos grupos da Amazônia, onde os xamãs mais poderosos são aqueles que têm, como espíritos familiares, temíveis predadores omófagos e hematófagos (ver Fausto 1999, 2001). No caso dos Guarani contemporâneos, contudo, rompeu-se essa articulação: o xamã é um anticanibal e os espíritos que lhe fornecem os cantos são as almas-divinas que habitam o "país dos mortos", ou são elas mesmas divindades sem características predatórias. Quando o antropólogo Miguel Alberto Bartolomé foi iniciado por seu informante, o pajé chiripá Avá Ñmbiara, este lhe disse para pensar no animal que acabara de matar, sem lhe dizer se isso era bom ou ruim. Em seguida, faloulhe da dieta vegetariana que deveria seguir e instou-o a deixar-se reger apenas pelo amor (Bartolomé 1977:103). O canibalismo como modelo de relação com outrem parece ter sido substituído por outra forma relacional, cuja categoria central é o amor (mborayhu $)^{26}$.

A disjunção entre xamanismo e predação, bem como a associação exclusiva do primeiro a uma alma divina imorredoura abriram caminho para uma transformação na noção de pessoas guarani e o surgimento do conceito de acyguá, essa alma-dor, animal e vigorosa, que representa o outro dos deuses e do desejo humano de imortalidade. O acyguá é, pois, o que nos prende a essa existência de infortúnios (teko achy) e nos impede de atingir a terra sem mal (ywy marã'ey) (H. Clastres 1975:114). Alteridade constitutiva, a alma-animal deve ser negada e limitada por uma dieta antivenatória, uma estética (veja-se a produtividade dos conceitos de belo e adornado) e por aquilo que vários autores denominaram, talvez sob influência de Ignácio de Loyola, "exercícios espirituais". A pessoa ideal masculina não é aqui a do guerreiro, que ao matar sua vítima captura uma alma-outra que é fonte de conhecimento e criatividade, mas a do xamã que se desfaz de sua alteridade para voltar a ser divino, à imagem de um deus que não é um jaguar.

\section{A religião do milho}

Voltemos à imortalidade corpórea, aquela que elide a prova da morte. Como vimos, ela é reservada aos grandes ascetas que atingem a maturação-perfeição (aguyje) e não ao matador. Conta-nos um xamã chiripá: "nosso antepassado foi-se em vida sem morrer [...] com este nosso corpo se foi e enquanto ele que se foi dança, nós dançamos também [...] Por isso, para dançar, nós não devemos comer carne, só devemos comer o 
que Nanderu [Nosso Pai] nos mandou" (Bartolomé 1977:87). Mas quais são os alimentos que Nosso Pai nos legou?

No caso dos Chiripá estudados por Bartolomé, parte da resposta encontra-se em um episódio mítico, inserido na famosa saga dos gêmeos e que não tem paralelo, ao que eu saiba, entre os Tupi-Guarani da Amazônia. Conta-se que toda vez que Kuarahy — o Sol, filho de Nanderú Guazú (Nosso Grande Pai) e o mais velho dos gêmeos - criava um animal, o Añang (o "demônio" tupi-guarani) inventava um modo de caçá-lo. A predação cinegética aparece, pois, não como um dado a priori ou como uma condição dada pelo demiurgo, mas sim como uma artimanha de seu rival canibal. O mito parece querer marcar, pois, a disjunção absoluta entre a divindade e a predação, de tal forma que o xamã está livre para operar na relação com seres divinos que não são predadores à maneira dos espíritos familiares de xamãs amazônicos.

Se a carne deve ser evitada, há alimentos que devem ser consumidos. Dentre eles, sobretudo, o milho branco, centro de um dos principais rituais contemporâneos: o avatikyry, glosado freqüentemente como "batismo do milho", cujo sentido literal é bebida fermentada de milho. Trata-se, pois, de uma cauinagem, mas bastante diversa da que realizavam os Tupinambá antes do festim canibal, ou da que realizam os Parakanã para tornaremse rápidos e caçar. O cauim guarani não os transforma em predadores ágeis e vorazes, mas os faz leves para aproximarem-se das divindades.

A festa é realizada para batizar a nova colheita de milho e assemelhase aos rituais amazônicos de xamanização do alimento para torná-lo comestível: "temos que tê-lo com amor, porque ele [o milho] é uma criança, temos que cantar para que amadureça [...] para que quando o comamos [...] não nos faça crescer a barriga, nem nos deixe nervosos. Deve-se rezálo para que não nos mate" (Maria Kaiová citada por Chamorro 1995:91. Ver também Schaden 1954a:57) ${ }^{27}$. O milho para os Guarani é uma pessoa, sendo preciso xamanizá-lo a fim de que torne-se seguro para o consumo cotidiano. Comê-lo não rezado, não tê-lo com amor, equivaleria a uma forma de canibalismo.

Podemos pensar também o batismo do milho kaiová como uma transformação de ritos indígenas pela apropriação de temas católicos. Não tanto pela presença da cruz, do altar (mba'e marangatu), das genuflexões ou mesmo de certos personagens (como Noé) nos cantos, mas sobretudo pela idéia de que se trata do batismo de Jakaira, a divindade que criou a segunda terra após o dilúvio, função que outros grupos guarani atribuem a Ketxu Kíritu (Schaden 1964:109, 110, 123). O tema do ritual é a renovação do milho e se dá ao termo do seu processo de maturação, que corresponde 
à partida da divindade: o corpo do milho fica para ser comido, enquanto seu "dono" (avati jára) parte para os céus, de onde retorna a cada novo plantio. Se nos arriscarmos a pensar esse ciclo como contendo um vestígio da saga de Cristo, e o milho como o seu corpo, a que corresponderia o sangue senão ao vinho indígena? Essa parece ser a função do cauim, que embriaga, mas os faz corretos e mansos, ao contrário da cerveja tupinambá ou das substâncias - freqüentemente associadas ao sangue das vítimas e ao sangue menstrual - que, nos rituais amazônicos, incutem um vigor violento e criativo nas pessoas (ver Fausto 1999). Para os Kaiová, o milho é dotado de um princípio chamado jasuka, que é sua força vital e lhe garante a renovação constante, não o deixando morrer, nem envelhecer. Paulito Kaiová explica assim o conceito: o cauim "é o primeiro sumo de Jasuka [...] Jasuka é para nós o que o motor é para os brancos, com a diferença de que o jasuka é natural, não artificial [...] Ele serve para darnos vida e nos renovar. Algumas pessoas são renovadas a tal ponto por Jasuka que já não morrem, permanecem novas como uma criança de lábio recém-furado" (Chamorro 1995:99).

A bebida fermentada aparece também em outro ritual kaiová, a furação labial dos meninos, conhecida, entre outros nomes, por mitä ka'u, "embriaguez da criança". O objetivo da cerimônia é cozinhar os jovens para que não se tornem violentos e nervosos (Chamorro 1995:115). Aqueles sem lábio furado permanecem crus e tendem a se tornar ou predadores ou presa, pois são "mais cheiroso[s] para as onças" (Schaden 1954a:111). O ritual, interdito às mulheres, visa produzir disposições pacíficas, não instalar uma potência predatória no jovem como ocorria nos ritos tupi-guarani do passado, na iniciação dos meninos entre os Barasana (C. Hugh-Jones 1979) ou na busca do arutam entre os Jívaro (Descola 1993). Paramentados com as roupas e os adornos rituais, os quais também entram em reclusão, os meninos tornam-se "verdadeiro[s] filho[s] de Tupã", crianças "sem males" (marane'y) (Chamorro 1995:111,118).

A "bebedeira de menino" é um ritual de cozimento e resfriamento dos iniciandos: a festa os "faz frios" (emboro'y) e os prepara para viverem segundo o "modo de ser frio" (teko ro'y), não-violento, um tema elaborado pelos cantos-reza:

Meu pai esfria o nosso mútuo corpo, alegrando a terra

Meu pai esfria a nossa mútua palavra, alegrando a terra

Meu pai esfria o bravo, alegrando a terra

(Chamorro 1995:115-116) ${ }^{28}$. 
Talvez esse mesmo "esfriar" já estivesse presente no universo reducional seiscentista, quando Montoya compôs seu Vocabulário e Tesouro da Língua Guarani, escrevendo no verbete da palavra Roi ("frio") as seguintes expressões: Roiçã hápe ahaihú Tûpã, "amo friamente a Deus", e Cheracubo cûe Tûpã raihûbari iroi imã, "esfriei-me no amor de Deus".

\section{A atividade do esquecimento}

Passemos, agora, à segunda questão, que versa sobre o problema da transformação e da duração e que expressei, de um ponto de vista fenomenológico, da seguinte forma: como é possível não ser o mesmo e continuar a pensar-se como si mesmo? Ou adaptando-a ao nosso objeto: como os Guarani fizeram plenamente seu um discurso religioso que traz as marcas de um discurso-outro? Como podem ser eles verdadeiramente os "filhos da Cruz da Boa Palavra"?

O universo religioso guarani está repleto de símbolos, rotinas rituais e personagens de origem católica. Vários autores, em particular, Schaden, dedicaram-se a identificar esses elementos. No plano das divindades, há uma proliferação de figuras "católicas", começando por uma divindade suprema, chamada de "Nosso Pai" (Ñanderu) ou "Nosso Senhor" (Nandejara), que se autoconcebe nas trevas primordiais, adornado por uma coroa de flores da qual emerge o pássaro primígeno, o colibri, que aparecerá em seguida como mensageiro dos deuses (Cadógan 1959:14; Clastres 1974:18; Bartolomé 1977:105). Na versão apapocuva, Ñanderuvuçu vem só na escuridão em que lutam os morcegos eternos, seres hematófagos que são a sua antítese. No peito, ele traz o sol (Nimuendaju 1987:143), esse coração resplandescente tão recorrente no imaginário religioso guarani, e que parece remontar ao culto do sagrado coração ${ }^{29}$. Os Chiripá dizem que quando alguém alcança o estado de perfeição (aguyjé), quando se está seco e incorruptível (kandire) brotam-lhe "chamas do peito como evidência de que seu coração está iluminado pela sabedoria divina" (Bartolomé 1977:84-85). A mesma sabedoria que permitiu a Namandu $R u$ Ete engendrar de si mesmo o brilho da flama e criar o fundamento da linguagem humana (ayvu rapyta), para então conceber o fundamento do amor (mborayú rapyta) (Cadógan 1959:19-20).

Quando passamos para a saga dos gêmeos, que inaugura, como diria Cadogan, a segunda parte dos "anais religiosos" dos Mbyá do Guaíra, a figura de destaque é Kuarahy, o Sol, o irmão mais velho da Lua. Entre os Mbyá de outras regiões, Kuarahy confunde-se com Kétxu 
Kíritu e com o Ketxuíta, personagens muitas vezes identificadas entre $\mathrm{si}^{30}$. Os Mbyá de Chapecó diziam que após a destruição da primeira terra pelo dilúvio, Kétxu Kíritu recriou o mundo (Schaden 1964:109, 123), este mundo que está, mais uma vez, prestes a se acabar, pois a cruz que o sustenta logo irá ceder. Os deuses virão então com "ponchito, chiripa e tembeta de fogo destruidor, piraguái [...] [e] toda a terra irá queimar" (Chamorro 1995:63). Haverá um novo dilúvio. Os deuses mudarão então pôr roupas frias (ro'y), as suas roupas destruidores, e prepararão a nova terra perfeita e eterna, "que nulle petitesse n'altère" (P. Clastres 1974:140).

Entre os Mbyá do Guaíra, a saga dos gêmeos é submetida a uma transformação significativa. Nesse mito de difusão pan-americana, temos, em geral, dois irmãos gestados no ventre da mesma mãe, mas produzidos por pais diferentes. Entre os Tupi-Guarani, freqüentemente o mais velho é filho do demiurgo Maíra e representa o xamanismo e a imortalidade, enquanto o mais novo é filho da mucura, símbolo da morte e da podridão. Nas "Belas Palavras", porém, o Sol cria a Lua de si mesmo após a mãe ser morta pelos jaguares: ele faz um companheiro, a quem chama de irmão, mas nega sua gemelaridade, pois eles sequer partilharam o mesmo útero ${ }^{31}$. Talvez se possa ler aqui um fato mais geral, se tivermos em mente que, seguindo Lévi-Strauss (1991), o mito dos gêmeos trata da impossibilidade de uma identidade perfeita e expressa "a abertura ao outro" que caracteriza as cosmologias ameríndias. Seria descabido pensar que as transformações guarani representariam uma deriva à tentação identitária, esse pli sur soi-même de que falava P. Clastres, e que, conseqüentemente, ele estava certo, exceto pelo fato de que as Belas Palavras não estiveram jamais "ao abrigo de toda mácula"?

Todas as marcas de um discurso-outro, todos esses signos de transformação, não levaram os Guarani, porém, a se pensarem como outros, pois eles fizeram essa alteridade plenamente sua. Isso implicou um esquecimento do processo pelo qual se apropriaram de e transformaram uma alteridade que, simultaneamente, os transformou. Mas como definir essa outra forma de olvido? Seria simples falha de memória de uma sociedade sem escrita e sem história - um mero pathos infeliz que bloqueia a consciência de que a atividade humana é um fazer inscrito na temporalidade ou seria um fenômeno ativo-passivo que supõe um mecanismo específico de produzir o mundo sociocultural e a memória coletiva? Ao analisar processo semelhante entre os Yanesha, Santos-Granero (m.s.) sugere que tal mecanismo resulta de uma combinação de mimetismo e esquecimento, cuja função seria reverter ou neutralizar assimetrias relacionais por meio da apropriação do poder do outro como se este fosse desde sempre próprio. 
Indo um pouco além, talvez pudéssemos ver nesse processo, como sugere Severi (2000), um modo paradoxal da memória social, capaz ao mesmo tempo de obliterar e gravar, em uma forma imagética e ritual, a representação de uma história traumática. Daí talvez a tristeza que os Guarani afirmam perpassar o batismo do milho, e que dificilmente se compreende no contexto mais geral dos rituais amazônicos, freqüentemente traduzidos pelos próprios índios como "festa"

Esse tema da apropriação e do esquecimento já assombrava os jesuítas no Brasil quinhentista. Para os padres, a dificuldade em converter os Tupi-Guarani residia em uma memória e em uma vontade defectivas para as coisas de Deus, pois se consumiam avidamente as Novas do Reino, logo delas se esqueciam. Como sugere Viveiros de Castro, "o problema [...] é determinar o sentido deste misto de abertura e teimosia, docilidade e inconstância, entusiasmo e indiferença com que os Tupinambá receberam a boa nova; é saber o que era esta 'fraca memória' e esta 'deficiência de vontade' dos índios, este acreditar sem fé; é compreender, enfim, o objeto deste obscuro desejo de ser outro, mas segundo os próprios termos" (Viveiros de Castro 1992a:26).

Se essa combinação de abertura e teimosia era uma característica estrutural da relação dos povos tupi-guarani com os brancos, a situação histórica colonial também a favoreceu. As epidemias, as migrações forçadas, o esgarçamento das redes sociais, a mestiçagem, os novos contextos interétnicos que reuniam pessoas de diferentes origens, tudo isso rompia as cadeias de transmissão tradicionais, ao mesmo tempo em que abria caminho para novas versões e reinvenções culturais. A própria descontinuidade do processo colonial, que ao sabor dos ciclos econômicos e das variações políticas, ora avançava, ora recuava sobre os territórios indígenas, ora atraía, ora repelia as populações nativas, reforçava a atividade do esquecimento $^{33}$. A dinâmica de fluxo e refluxo - que deve ser lida no tempo e no espaço, e que incluía fenômenos que escapavam aos olhos e ao controle dos conquistadores - tornava possível às sociedades nativas reelaborarem e recriarem com certa autonomia conteúdos que eram produzidos e circulavam em períodos ou em regiões de interação interétnica mais densa. Esses fatos, raramente documentados, tenderam a ficar esquecidos, pois a etno-história concentrou-se nos momentos de expansão do sistema e ali onde havia interação contínua entre brancos e índios. Daí ter-se criado a impressão de que a história indígena era história apenas nessa relação e que, portanto, só caberiam duas alternativas de análise: ou a história indígena resume-se à imposição gradual e inexorável de um modelo externo dominante (e portanto é simples história dos outros), ou 
ela é a repetição do Mesmo, contra a alteridade da própria história, afirmação do idêntico a despeito da passagem do tempo.

\section{Conclusão}

Para fundar uma nova ética do amor (mborayhu) - que provavelmente se ergueu sobre conceitos nativos como a generosidade e a reciprocidade, e se nutriu do "amai-vos uns aos outros" da mensagem cristã —, os Guarani ocultaram as pegadas do jaguar. Fizeram dele pura negatividade ou cercaram-no de silêncio. Se o banco zoomorfo (apyka) do xamã-asceta representa com freqüência o felino, falta-lhe porém a cabeça, pois "não se deve ver, nem reconhecer o jaguar. Muito menos deve-se nomeá-lo" (H. Clastres 1975:133).

Nas missões, ensinava-se a imitar o pathos de Cristo (e dos padres) e, ao mesmo tempo, a não se apropriar da agência do jaguar. Nas cartas Ânuas, a associação entre 'tigres del monte', feiticeiros e demônio é recorrente, conforme notou Wilde (com. pessoal). Para os jesuítas, afinal, tratavase de um só e mesmo combate. O Deus-feito-homem subvertia a lógica predatória das ontologias indígenas: o pólo divino tornara-se o da presa passiva, fato que se manifestava a cada ato de comunhão ${ }^{34}$. Do inimigo comido em praça pública à divindade devorada na missa havia, pois, um longo passo, que exigiu transformações significativas. Pense-se a notável ausência do sangue nos rituais e cosmologias guarani, um símbolo tão central às culturas indígenas quanto ao cristianismo. O sangue de Jesus, signo de um sacrifício (um pathos) que os missionários desejavam imitar na forma do martírio, não podia ser apropriado, uma vez que ele é, nas ontologias ameríndias, a substância criativa-transformativa por excelência, associada a um surplus de atividade predatória. A ética da mansidão e o xamanismo ascético exigiam uma nova combinação entre três substâncias transformadoras: o sangue, o cauim e o tabaco. Os Guarani aproximaram as duas últimas e negaram a primeira. Não é à toa que Jakaira, dono do milho com que fazem a cerveja, é também aquele que criou o tabaco para defender os seres humanos do infortúnio.

Todo esse processo de transformação não foi aleatório e amorfo, como se poderia imaginar: apropriações e reapropriações, traduções e retraduções, interpretações e reinterpretações, em um contexto de crise sociodemográfica, não produziram um sem-número de cosmologias incomparáveis. Ao contrário, é possível falar hoje em uma cosmologia guarani contemporânea e reconhecer, na variação, versões de uma estrutura em 
transformação. Pode-se apontar também certos motivos cristãos que tiveram particular produtividade, como é o caso do amor. Os missionários conquistavam os índios, como diria Montoya, "com amor e dádivas" (1985:208) — e, claro, também com a ação armada de espanhóis e índios fiéis ${ }^{35}$. Mas não se despreze o amor devoto do missionário que, ao ser massacrado, pergunta para seus algozes: "filhos, por que me matais?" (1985:200). O imperativo do amor teve um impacto mais duradouro no pensamento guarani do que o da punição e o do inferno, assim como parece ter ocorrido entre os Yanesha descritos por Santos-Granero (1991).

A passagem da predação ativa ao amor passivo não implicou, contudo, o desaparecimento absoluto da violência e da devoração mas, possivelmente, sua focalização no campo da violência mágica. No caso Kaiowá-Ñandeva, Mura (s.d.a) argumenta em favor de uma "transposição da antropofagia para o plano negativo da feitiçaria", vista como uma forma de devoração. Mura aponta ainda para o aparente paradoxo entre a descrição das fontes do século XIX sobre a 'mansidão' dos Kaiowá e Ñandeva e os conflitos entre parentelas que, nas primeiras décadas do século $\mathrm{XX}$, conduziram à dissolução de unidades políticas e à morte de muitas pessoas devido a acusações de feitiçaria ${ }^{36}$. Seja como for, parece-me que estamos diante de uma verdadeira mudança de ponto de vista, em que a constituição da pessoa e do coletivo indígenas passam por uma identificação não mais com o pólo predador da relação com outrem, mas com o de presa familiarizável ${ }^{37}$.

Qual teria sido, contudo, a brecha através da qual a mensagem cristã do amor universal e da irmandade entre os seres humanos penetrou no mundo vivido indígena? Ela parece ter reverberado justamente onde a predação se projeta sobre as relações sociais entre parentes, onde uma ética da reciprocidade e da generosidade bascula diante do canibalismo como mecanismo necessário de reprodução social. Eis a questão: como evitar que a predação no exterior se torne a medida das relações interiores, como ser jaguar sem comer os próprios parentes? Ali onde esse problema foi posto de modo agudo, assistimos a um conjunto de transformações na noção de pessoa, na dieta e nas práticas rituais. Nem sempre estas resultaram da influência cristã ou mesmo da presença européia, pelo menos não diretamente. No caso alto-xinguano, por exemplo, ela parece ser antes o produto de um fundo cultural arawak e de uma necessidade histórica de acomodamento entre povos de línguas e etnias diferentes, em um contexto de pressão territorial provocado pela Conquista (ver Heckenberger 2005; Franchetto \& Heckenberger 2001). No caso do alto rio Negro, por sua vez, a redução do espaço da predação envolve uma longa história de contatos com agentes coloniais seguidos por períodos de isolamento, em 
um contexto de acomodação entre diferentes etnias (Hugh-Jones 1994, 1996:145; Wright 1998).

Embora não possa me deter nesses casos, gostaria de terminar com algumas observações sobre o que S. Hugh-Jones (1994) chamou de "xamanismo dual" entre os povos do alto rio Negro; a saber, a distinção entre dois tipos de especialistas religiosos, que atraem diferencialmente os pólos complementares do xamanismo amazônico: o pólo-jaguar e o pólo-divindade, o sangue e o tabaco. A disjunção que apontei para os Guarani aparece aqui como um elemento constitutivo do xamanismo tukano e baniwa, desde pelo menos o século XIX, nas figuras do payé (o xamãjaguar, moralmente ambíguo, voltado para as relações exteriores e associado à caça e à guerra) e do kubu (o xamã-divindade, pacífico e generoso, voltado para as relações com ancestrais e associado aos rituais coletivos de passagem e ao batismo dos primeiros frutos).

Tal dicotomia, ao contrário do caso guarani, implica complementaridade de funções e não negação de um de seus pólos. Contudo, desde o final do século XIX, observa-se a morte progressiva dos xamãs-jaguar no alto rio Negro, que haviam conhecido um período de florescimento durante os movimentos messiânicos que se difundiram na região a partir de 1857. Segundo S. Hugh-Jones (1994), os líderes desses movimentos, os "pajés da cruz", eram pessoas com experiência da sociedade colonial, que reuniram o xamanismo do jaguar a elementos cristãos. Com o declínio do profetismo e a efetiva instalação de novas missões católicas na região, assistiuse a uma crescente rejeição dos xamãs-jaguar, cujo estatuto está associado tanto à guerra quanto à caça (Hugh Jones 1994:145).

Os xamãs guarani que, no século XVI e XVII, lideraram grandes ou pequenas revoltas contra o sistema colonial, eram, em toda evidência, também guerreiros e jaguares: cantavam e dançavam, bebiam cauim, profetizavam, favoreciam a caça e a guerra e talvez continuassem a comer carne humana. Talvez continuassem também a desejar, como nas Santidades do século XVI, que os invasores brancos fossem convertidos em caça para eles comerem (Monteiro 1999:1012). Todos acabaram, porém, vencidos pela repressão violenta, pela ação missionária, pelas epidemias, pelas rivalidades internas ou pela descrença. Os xamãs contemporâneos, talvez fechados pelo lado "desta praxis", fundaram sua ação e sua autoridade em uma outra fonte, o amor (mborayhu), e em outra prática, a ascese. Por isso, eles podem recriminar os brancos por não terem aquilo que, um dia, lhes disseram que eles não tinham: "[Se] este mundo vai mal e encaminhase para a destruição", disse Ñanderu Fernando Taparí ao antropólogo, "é porque os civilizados são pouco religiosos" (Schaden 1964:117). 
Recebido em 21 de março de 2005

Aprovado em 20 de setembro de 2005

Carlos Fausto é professor adjunto do PPGAS/ Museu Nacional/ UFRJ, pesquisador do CNPq e do Núcleo de Transformações Indígenas (NuTI-Pronex).

\section{Notas}

*Este texto foi escrito em 2001, durante minha permanência no Laboratoire d'Anthropologie Sociale (CNRS/Collège de France). Publico-o aproximadamente tal qual o escrevi na época, acrescentando novas referências e comentários onde julguei indispensável. Agradeço a Philippe Descola por me receber no LAS e a CAPES por prover os meios para minha estadia na França. Diferentes versões deste texto foram apresentadas na École Pratique des Hautes Études, na Maison de Sciences de L'Homme, no Laboratoire d'Anthropologie Sociale, no Centre André-Georges Haudricourt (CNRS-Villejuif), no Instituto de Filosofia e Ciências Sociais (UFRJ) e na Universidade de Chicago. Beneficiei-me de questões e críticas de muitas pessoas nessas apresentações, e não posso fazer justiça a todas elas aqui. Assim, agradeço, em nome de todos os outros, a Patrick Menget, Guillaume Boccara, Anne-Christine Taylor, Carlo Severi, Olivier Allard e Manuela Carneiro da Cunha. Agradeço, especialmente, a John Monteiro, Fabio Mura, Guillermo Wilde e ao parecerista anônimo pelos comentários generosos ao manuscrito.

${ }^{1}$ Os Guarani somam, hoje, cerca de 100 mil pessoas. Dividem-se em quatro macroblocos: os Kaiová ou Paï-Taviterã com 17 mil indivíduos vivendo no Brasil e no Paraguai; os Mbyá com 12 mil pessoas distribuídas no litoral brasileiro, no Paraguai e na Argentina; os Chiripá ou Ñandeva cuja população de 8 mil pessoas vive no Brasil e no Paraguai; finalmente, os Chiriguano cuja maioria dos 60 mil índios encontra-se na Bolívia (Chamorro 1998:46). A citação inicial é retirada de Chamorro (1995:35). Alterei a tradução de ara de "universo" para "tempo".

${ }^{2}$ Desde a década de 1550, a idéia de que os Guarani eram mais permeáveis à catequese do que os Tupi circulava entre os Jesuítas no Brasil, em particular em São Paulo, onde se encontrava a fronteira entre os dois grandes blocos tupi-guarani (Monteiro 1992:487). Como indica Viveiros de Castro (1992a), havia uma boa dose de idealização nesse julgamento.

${ }^{3}$ Ver, por exemplo, as coletâneas organizadas por Wright $(1999,2004)$ e os trabalhos históricos de Castelneau-L'Estoile (2000), Pompa (2003) e Wilde (2003a). 
${ }^{4} \mathrm{O}$ equívoco mais comum é tomar a tradição etnológica sobre os Guarani como a descrição dos Guarani pré-conquista e, portanto, como ponto-zero a partir do qual se medem as transformações pós-conquista. Essa projeção etnográfica sobre o passado histórico leva a uma circularidade viciosa, na qual fatos posteriores passam a explicar fatos antecedentes (veja-se, por exemplo, a caracterização dos Guarani pré-missão feita por Bailey (1999:148-150). Outro erro comum é a condensação espacial e temporal: assim, uma migração tupi originada na costa de Pernambuco em meados do século XVI, é usada como evidência para o caráter originário da busca da Terra sem Males pelos Guarani, que só seria observada a partir do século XIX. Por fim, o hiato disciplinar faz com que, por vezes, historiadores utilizem dados etnográficos de maneira conceitualmente problemática, como ocorre, por exemplo, com a caracterização da cultura guarani por Ganson (2003:17-24).

${ }^{5}$ Por se tratar de uma leitura da produção sobre os Guarani em geral, não distingo com a devida fineza as diferentes situações etnográficas e históricas envolvendo os distintos grupos guarani. Limito-me, ademais, à visão hegemônica sobre os pajés e a religião. Suspeito que haja mais a dizer sobre o xamanismo contemporâneo no que toca, por exemplo, às acusações de feitiçaria e à violência mágica, algo que uma análise de casos particulares poderia revelar (ver Mura s.d.a para os Kaiowá e Lowrey 2003 para os Izozog Chiriguanos).

${ }^{6}$ Edelweiss (1947 e 1969) procurou rastrear essa informação na literatura. Montoya parece ter sido o grande consolidador do termo guarani.

${ }^{7}$ Sobre a resistência guarani, ver, entre outros, Susnik (1965:215-228; 1979-80:164172), Necker (1979), Meliá (1986:31-41), Rípodas Ardanaz (1987) e Roulet (1993).

${ }^{8}$ No início do século XVII, toda uma legislação dispondo sobre a relação entre índios e não-índios vem reforçar o poder das ordens religiosas e restringir a ação dos encomenderos. Em 1603, é realizado o primeiro sínodo diocesano do Rio da Prata, em Asunción. O governador Hernandes Arias edita em seguida ordenanças que prolongam as constituições do sínodo. Em 1611, editam-se então as Ordenanças de Alfaro, que constituíram um verdadeiro código dispondo sobre a relação entre índios e brancos durante boa parte do período colonial (ver Necker 1979:118 e ss.).

${ }^{9}$ No século XVIII, fortes oscilações ocorreram entre 1715 e 1720, entre 1735 e 1740, como também após o Tratado de Madrid (1750) e a chamada guerra guaranítica (1754-1756) (Ganson 2003:108-112).

${ }^{10}$ Trinta anos após a expulsão, a população das 30 missões jesuíticas da bacia ParanáParaguai, que era de quase 90 mil pessoas em 1768, havia caído pela metade. A depopulação resultou do efeito combinado de epidemias e migrações. Muitos Guarani rumaram para cidades, outros encontraram ocupação no campo. Inseriram-se temporária ou definitivamente na economia local como trabalhadores não qualificados, peões, vaqueiros, artesãos, padeiros (Ganson 2003:125-136). Outros ainda, sobre os quais sabemos muito pouco, retornaram à mata, tornando-se uma vez mais monteses. Para uma descrição das transformações sociais posteriores à expulsão dos jesuítas, ver Wilde 2003a, capítulo 5. 
${ }^{11}$ Nimuendaju assim explica sua tradução: “[...] Terra sem Mal, Yvy marãey. Marã é palavrra que não mais se utiliza no dialeto Apapocúva; em Guarani antigo significa 'doença', 'maldade', 'calúnia', 'luto-tristeza' etc. Yvy significa 'terra', e ey é a negação 'sem'" (1987:38). Melià (1986:106) sugere que o significado, no século XVII, de ywy marane'y fosse aquele dado por Montoya (1876) de "solo intacto", e que este só teria adquirido uma conotação religiosa no século XIX, quando se observam as migrações de que trata Nimuendaju (Melià 1990:45). Noto, ademais, que o termo marane'y era um conceito extremamente produtivo nas missões, designando a virgindade de Nandesy (Nossa Mãe), a castidade dos padres, a pureza e a ausência de pecado (ver Montoya 1876). Em Parakanã, temos o cognato -marony'ym, que aparece nas narrativas guerreiras com o significado de "não ferido", "intocado". Para uma análise crítica, ver, além de Melià (1990), Noelli (1999), Pompa (2000).

${ }^{12}$ Alguns grupos mbyá identificavam esse local como a "Terra do Ketxuíta" ou de "Ketxu Kíritu" (Schaden 1964:123). Schaden conta o episódio tragicômico dos Mbyá do litoral paulista que, nos anos 1940, foram ter com o Presidente da República, "a fim de obterem passagens marítimas para Portugal, que julgavam ficar mais perto do Paraíso" (1954a:178). Não conseguiram. Em vez, foram transferidos para o aldeamento de Pancas que, ironicamente, ficava no estado do Espírito Santo.

${ }^{13}$ Isso se deve a vários fatores, alguns internos à antropologia, outros externos. Nas décadas de 1940 e 1950, assiste-se, ao menos no Brasil, a uma valorização das noções de tradição e de preservação cultural, que conduziriam a mudanças importantes na política indigenista do Estado brasileiro. O Parque Indígena do Xingu e o indigenismo villas-boasiano são exponentes desse movimento que ganharia sua expressão máxima no artigo 231 da Constituição Federal de 1988. Desde então, no entanto, os ventos da pós-modernidade e da condição pós-moderna afetaram substancialmente o paradigma preservacionista. Sem a bússola absoluta da cultura pura, o campo de lutas político-ideológicas vem-se reconfigurando em torno de novas categorias-chave, tais como patrimônio imaterial e propriedade intelectual (ver Fausto 1998).

${ }^{14}$ Não me cabe aqui analisar esta hipótese de P. Clastres. Noto apenas que as bases arqueológicas e históricas são frágeis.

${ }^{15}$ Esse ideário de identidade e espiritualidade aproximou da etnologia a tradição missionária cristã pós-Concílio Vaticano II, que viu nos Guarani uma expressão forte da religiosidade humana em geral (se a alma divina é-nos comum, a espiritualidade é necessariamente anterior ao Evangelho e, portanto, à Igreja). O limite dessa postura tolerante é o caráter único ou especial da Revelação cristã, necessária para legitimar a própria instituição. Outro tipo de postura "tolerante" tem aparecido, recentemente, no missionarismo evangélico. A rede Fale, reunindo organizações evangélicas, faz hoje campanha em favor da "liberdade religiosa dos povos indígenas" em nome do "direito à livre escolha" (ver www.fale.org.br). Em um de seus panfletos, lê-se, ao lado de frases de pastores indígenas, uma declaração de Marcolino da Silva, identificado como "pajé guarani": "Eu respondi [a um pastor que apareceu na minha aldeia]: não, desculpe-me. Pode pegar a sua Bíblia, o seu carro e se mandar [...] eu tenho a minha própria religião [...] e não posso trocar minha religião por outra religião." Plus ça change, plus c'est la même 
chose: os Guarani continuam a ser os únicos índios das terras baixas sul-americanas a quem as igrejas cristãs (e alguns etnólogos) gostam de atribuir uma verdadeira religião.

${ }^{16}$ É significativo notar a presença de mestiços entre os seguidores de Overá. Mestiços e índios com experiência reducional tiveram participação destacada em vários movimentos "messiânicos", sugerindo que ocupavam uma posição de mediação importante na circulação e na digestão de novas idéias (ver Hugh-Jones 1996:53). Pense-se nas figuras de Juan Santos Atahualpa que comandou o levante dos Arawak pré-andinos no século XVIII (Santos-Granero 1993), ou de Venâncio Cristo e seus sucessores que se fizeram profetas entre os Baniwa no século XIX (Wright \& Hill 1986). Veja-se também a análise de Vainfas (1995) sobre a chamada Santidade do Jaguaripe, que eclodiu no Recôncavo baiano na década de 1580, e cujo imaginário parece ter sido gestado nos aldeamentos da Companhia de Jesus.

${ }^{17}$ Esse é um fenômeno que se observou em todo o Novo Mundo, pois da convergência entre as funções de missionários e xamãs derivava uma rivalidade inevitável. Como chamou a atenção Gruzinski (1974), quando o padre procurava demonstrar sua superioridade sobre o xamã enquanto especialista religioso, ele admitia combatê-lo em seu próprio campo e, portanto, facilitava sua incorporação à cosmologia nativa. Os jesuítas, em especial, souberam utilizar-se com maestria dessa convergência, tanto na América do Sul (Haubert 1966, Fausto 1992, Viveiros de Castro 1992b), como na América do Norte (Griffiths 1999:15-18; Steckley 1992).

${ }^{18}$ Os índios não se mostravam refratários em matéria de fé, mas em matéria de costume, sendo que, no século XVII, ao menos aos olhos de Montoya, o grande impedimento à conversão não era a antropofagia, mas sim a poligamia, em particular a dos chefes. A estes, a Coroa Espanhola reconhecia um estatuto especial, dava-lhes título e um bastão-insígnia, eximia-os dos serviços obrigatórios e das encomendas, e a eles confiava a organização desse mesmo sistema em nível local (ver Ganson 2003:57-68, sobre a estrutura hierárquica das missões e o sistema dos cabildos). Nas reduções, freqüentemente excluídas da rede de encomiendas, os padres conquistavam-nos "à força de dádivas de pouco valor" (Montoya 1985:197) e exigiam que tomassem uma só mulher em legítimo matrimônio. Não raras vezes, os chefes rebelavam-se e mobilizavam não apenas tropas, mas também xamãs (muitos dos chefes, aliás, eram também pajés).

${ }^{19}$ Essa apropriação, como aponta Wilde, terá um efeito paradoxal no contexto missional do século XVIII, quando servirá como uma "potente via de agregação simbólica à sociedade dominante", em condições de subordinação (2003b:218). Wilde refere-se aqui aos bastões e outras insígnias conferidas ritualmente aos cabildantes indígenas pelos padres jesuítas. É difícil afirmar se, no passado pré-conquista, símbolos de poder semelhantes existiam entre os Guarani. O certo, contudo, é que os "bastões de poder" tiveram um impacto muito grande na religião guarani, aparecendo, por exemplo, no início das Belas Palavras, pois Nanderu traz a "vara insígnia" (ywyra'i) na palma de suas mãos (Cadógan 1959:14). Os chiru (cruzes e varas insígnias) kaiowá contemporâneos remetem a esse mesmo contexto. E não deixa de ser curioso que os assistentes dos xamãs kaiowá, que devem zelar pelos chiru, sejam denominados ywyra'ija (os "donos das varas"), tais como aqueles que, nas missões, ocupavam o cargo de aguazil (Mura s.d.b; Wilde 2003b:220). 
${ }^{20}$ Em sua Crónica Franciscana de las Provincias de Perú, Diego de Córdova Salinas conta que um espanhol, ao ver sua expedição cercada pelo fogo nos Pampas, usouse do manto de Pe. Bolaños para dominar o fogo e este "reconoció la virtud que Dios había puesto en él y, prestando a su poder obediencia, se apagó todo, dejando a los circunstantes tan maravillados como tiernos, de ver el respeto que el fuego tuvo al manto" ([1651] apud Necker 1979:49).

${ }^{21}$ Assim, por exemplo, no mito recolhido por Thevet no século XVI, no qual o herói cultural é incinerado pelos ancestrais dos Tupinambá; assim também em uma versão guarani da saga dos gêmeos, na qual a onça-avó tenta inutilmente assá-los e comê-los, mas é incapaz de destruir-lhes o corpo e termina por criá-los como animais domésticos (Cadogan 1959:73-74); finalmente, no mito jê de Aukê, que se transforma em Branco após ser incinerado pelo tio materno, o qual já tentara matá-lo diversas vezes por conta de suas constantes metamorfoses.

${ }^{22}$ Montoya parece crer que coisa semelhante ocorria com o corpo dos mártires da Igreja (ainda que eles morressem): quando os padres Afonso e Roque foram assassinados, "para que não ficasse qualquer rastro dos mártires, fizeram uma grande fogueira, em que jogaram os dois corpos e o coração do Pe. Roque. Ficou, no entanto, inteiro este, a vencer o fogo de caridades as chamas que ardiam a partir da lenha material, permanecendo como ouro depurado ao fogo a pureza daquele coração, que hoje se guarda em Roma com a mesma flecha que o atravessou" (Montoya 1985:203). Já os ossos do Pe. Roque foram conservados na Missão de Concepción. Às vésperas da Guerra Guaranítica que se seguiu ao Tratado de Madri (1750), um grupo de 70 índios armados para lá rumaria a fim de reverenciá-lo e solicitar proteção (Ganson 2003:95). Sobre a importância de Pe. Roque como símbolo guarani da aliança entre jesuítas e índios reduzidos, ver Wilde (2003b:98-99).

${ }^{23}$ Há variações importantes conforme o subgrupo guarani estudado. Aqui, tomo o caso mbyá, no começo do século XX, descrito por Nimuendaju, como tipo-ideal.

${ }^{24}$ Com exceção da carne do queixada, animal designado como o "belo bicho de estimação" de uma divindade (ver H. Clastres 1975:127; Ladeira 1992 e Larricq 1993).

${ }^{25}$ Faço economia aqui das variadas versões do destino póstumo da alma-palavra que se encontram na literatura guarani.

${ }^{26}$ Faltam-me dados para analisar a fundo essa categoria entre os Guarani contemporâneos, pois desconheço uma descrição fenomenologicamente densa desse afeto. Montoya utilizava o termo no século XVII para verter ao Guarani a noção cristã do amor de e $a$ Deus. Cadogan (1959) o traduz nas Belas Palavras por "amor (ao próximo)". P. Clastres o corrige, sugerindo que o sentido original de mborayu seria o de "solidariedade tribal" (1974:27), enquanto H. Clastres prefere o termo mais neutro "reciprocidade" (1975:116). Seria importante buscar na documentação histórica evidências de como se deu esse processo de transformação, focalizando não apenas as práticas repressivas e pedagógicas das Missões, como também as contradições e as angústias vividas pelas pessoas indígenas. Tais experiências talvez estejam gravadas em baixorelevo nas crônicas menos edificantes e na descrição de casos particulares. 
${ }^{27}$ A reza é o canto-dança que se realiza sob a direção de um xamã, um Ñanderu. Ela descreve o processo cíclico de renovação do milho, que amadurece sem nunca morrer, que adorna o corpo com roupas 'litúrgicas' e plumas e se faz novamente semente (Chamorro 1995:79-81).

${ }^{28}$ Em Guarani: "Che ru ojoeté emboro'y, embohory ywy // Che ru oñoñe'ë emboro'y emborohy ywy // Che ru piraguái emboro'y embohory ywy". Alterei ligeiramente a tradução de Chamorro. Sobre resfriamento e aquecimento no contexto de produção das varas-insígnias (chiru), ver Mura s.d.b.

${ }^{29}$ O culto ao Sagrado Coração, cuja iconografia característica é a do órgão no peito ou nas mãos de Jesus de onde emanam raios de luz em várias direções, data do final do século XVII, seguindo-se às aparições de Jesus a Santa Maria Margarita Alacoque a partir de 1673. O Sagrado Coração está fortemente associado à noção católica de amor. Em suas aparições, Jesus teria apontado para seu peito e dito a Santa Maria Margarita Alacoque: "Eis aqui o Coração que tanto amou os homens, que não poupou nada até esgotar-se e consumir-se, para testemunhar-lhes seu amor; e, por reconhecimento, não recebe da maior parte deles senão ingratidões, por suas irreverências, sacrilégios e pelas indiferenças e desprezos que têm por Mim no Sacramento do amor". Em Roma, na Igreja de Santo Inácio, encontra-se uma Capela do Sagrado Coração, que data provavelmente do século XVIII. No altar, há um quadro do final daquele século, em que — como explica uma pequena nota para os turistas - "Jesus aponta para o coração como símbolo de seu amor pelos homens". Não sei dizer se, antes da década de 1740, quando milhares de pinturas, esculturas e gravuras vindas da Europa chegaram à região, a imagem do Sagrado Coração circulava nas missões. Sabemos, contudo, que em 1744, aportaram nada menos do que 900 gravuras do coração de Jesus em um único barco (Bailey 1999:164).

${ }^{30}$ Outras versões sugerem que o Ketxuíta não era um deus, mas um Guarani do Paraguai que chegou ao estado de maturação-perfeição (Schaden 1964:109).

${ }^{31}$ Um informante de Cadogan explicou-lhe a ausência de gemelaridade no mito, remetendo à concepção de que o nascimento de gêmeos é uma punição divina contra o casal: "o índio jovem que me revelou a crença me disse que seria uma inconsistência muito grande que os Mbya adorassem a deuses gêmeos, se eles mesmos consideram os gêmeos como encarnação do Demônio e os eliminam ao nascer" (Cadogan 1959:70-71).

${ }^{32}$ Como diz um Kaiová, citado por Chamorro: "los que no son Kaiová creen que todo es fiesta y alegría en el jerosy; pero el jerosy es una tristeza!" (1995:94).

${ }^{33}$ Um esquecimento, aliás, de dupla face, pois permitia que também os brancos (incluindo os antropólogos) "re-descobrissem" populações que, muitas vezes, já haviam estado sob influência missionária, haviam comerciado com colonizadores ou a eles haviam resistido nos séculos anteriores. O boom da borracha, que varreu a Amazônia a partir de 1860, foi um desses momentos privilegiados de "re-descobertas", e nos legou muitas das designações que hoje compõem o mapa etnográfico da região. 
${ }^{34}$ Sobre o uso de imagens de Cristo e de mártires nas missões jesuíticas do continente para "incitar pathos", ver Bailey (1999:147; 167-169). Sobre a constituição ativo-passiva das relações e pessoas nas ontologias ameríndias, ver Fausto (2002c).

${ }^{35}$ As pestes tiveram também um papel relevante aqui, pois os missionários exploravam a idéia do castigo divino associando-o às epidemias (Montoya 1985:208). Como a população não-reduzida ou recém-reduzida deveria ser mais suscetível às doenças infecto-contagiosas do que aqueles nascidos ou criados nas Reduções, é possível que estas cobrassem maior número de vítimas entre as almas ainda recalcitrantes: "Aos demais delinqüentes desterrou-os a peste desta vida [...]. Muito deu na vista que a peste fizesse vítimas somente entre eles, pois esta esqueceu os do povo restante, que conservaram saúde e vida" (Montoya 1985:191).

${ }^{36}$ Para situação semelhante em que uma "religião do amor" é acompanhada de inaudita violência, ver o prefácio de Santos-Granero à edição em espanhol de "O Poder do Amor" (1994).

${ }^{37}$ Sobre essa inversão de ponto de vista, ver Rival para os Huaorani $(1998,2002)$ e Bonilla para os Paumari (2005), que mostram, ademais, que essa perspectiva invertida pode servir à resistência em contextos de grande assimetria de poder. No caso Paumari, Bonilla argumenta que se trata de um mecanismo sociológico poderoso, que lhes permitiu controlar a predação, colocando-se como presas familiarizadas de grandes predadores, isto é, clientes adotados por "bons patrões". 


\section{Referências bibliográficas}

ANDRADE, Lucia M. M. 1992. O Corpo e os cosmos: relações de gênero e o sobrenatural entre os Asurini do Tocantins. Dissertação de Mestrado, Universidade de São Paulo.

BAILEY, Gauvin A. 1999. Art on the jesuit missions in Asia and Latin America, 1542-1773. Toronto: University of Toronto Press.

BARTOLOME, Miguel Alberto. 1977. Orekuera Royhendu (lo que escuchamos en sueños): shamanismo y religión entre los Ava-Katu-Eté del Paraguay. Mexico: Instituto Indigenista Interamericano.

BONILLA, Oiara. 2005. "O bom patrão e o inimigo voraz: predação e comércio na cosmologia paumari". Mana. Estudos de Antropologia Social, 11(1):41-66.

CADOGAN, Leon. 1959. "Ayvu Rapyta: textos míticos de los Mbyá-Guarani del Guaira". Boletim 227, Antropologia 5. Universidade de São Paulo.

CASTELNEAU-L'ESTOILE, Charlotte. 2000. Les ouvriers d'une vigne stérile: les jésuites et la conversion des indiens au Brésil (1580-1620). Lisboa/Paris: Centre Culturel Calouste Gulbenkian.

CHAMORRO, Graciela. 1995. Kurusu Ne'ëngatu: palavras que la historia no podría olvidar. São Leopoldo: IEPG/ COMIN.

1998. A espiritualidade guarani: uma teologia ameríndia da palavra. São Leopoldo: Sinodal.

CLASTRES, Hélène. 1975. La terre sans mal: le prophétisme Tupi-Guarani. Paris: Seuil.

CLASTRES, Pierre. 1974. Le grand parler. Paris: Seuil.

DESCOLA, Philippe. 1993. Les lances du crépuscule: relations jivaros, Haute Amazonie. Paris: Plon.
DOBRIZHOFFER, Martin. 1970 [1784].An account of the Abipones, an equestrian people of Paraguay. Reprinting of the 1822 edition. III vols. New York: Johnson Reprint Corporation.

EDELWEISS, Frederico G. 1947. Tupis e Guaranis (estudos de etnonímia e linguística). Salvador: Publicações do Museu da Bahia, n. 7. 301 pp. .1969. Estudos Tupie Tupi-Guaranis: confrontos e revisões. Rio de Janeiro: Livraria Brasiliana.

FAUSTO, Carlos. 1992. "Fragmentos de história e cultura Tupinambá: da etnologia como instrumento crítico de conhecimento etno-histórico". In: M. Carneiro da Cunha (ed.), História dos índios no Brasil. São Paulo: FAPESP/ Cia das Letras/SMC. pp. 381-396. . 1998. "Lados demais? Fazendo política indigenista no ano 2000 $\mathrm{dC}$ ". Boletim da ABA, 30:19-22.

. 1999. "Of enemies and pets: warfare and shamanism in Amazonia". American Ethnologist, 26(4):933-956. . 2001. Inimigos fiéis: história, guerra e xamanismo na Amazônia. São Paulo: Edusp. 2002a. "Faire le mythe: histoire, récit et transformation en Amazonie". Journal de la Société des Américanistes, 88:69-90.

.2002b. "The bones affair: knowledge practices in contact situations seen from an amazonian case". Journal of the Royal Anthropological Institute, 8(4):669-690.

. 2002c. "Banquete de gente: comensalidade e canibalismo na Amazônia". Mana. Estudos de Antropologia Social, 8(2):7-44.

2003. "Masks, trophies and spirits: making invisible relations visible". Paper 
presented at the $51^{\circ}$ International Congress of Americanists, Santiago de Chile. Ms.

.2004. "Ablend of blood and tobacco: shamans and jaguars among the Parakanã of Eastern Amazonia". In: N. Whitehead \& R. Wright (eds.), In darkness and secrecy: the anthropology of assault sorcery and witchcraft in Amazonia. Chapell Hill: Duke University Press. pp. 157-178.

FRANCHETTO, Bruna \& M. HECKENBERGER (eds.). 2001. Os povos do Alto Xingu. História e cultura. Rio de Janeiro: EdUFRJ.

GANSON, Barbara Anne. 2003. The Guaraní under Spanish rule in the Río de la Plata. Stanford: Stanford University Press.

GREER, Allan. 2003. "Conversion and identity: iroquois christianity in seventeenth-century New France". In: K. Mills and A. Grafton (eds), Conversions: old worlds and new. Rochester: University of Rochester Press. pp. 175-198.

GRIFFITHS, Nicholas. 1999. "Introduction". In: N. Griffith and F. Cervantes (eds), Spiritual encounters: interactions between christianity and native religions in colonial America. Lincoln: University of Nebraska Press. pp. 1-42.

GRUZINSKI, Serge. 1974. "Délires et visions chez les indiens de Méxique". Temps modernes, 86:445-480.

HAUBERT, Maxime. 1966. L'oeuvre missionaire des jésuites au Paraguay 1585-1768: genèse d'un 'paradis'. Paris: Ecole Pratique des Hautes Etudes.

HECKENBERGER, Michael J. 2001. "Estrutura, história e transformação: a cultura xinguana na longue durée, 1000-2000". In: M. Heckenberger \& B. Franchetto (eds.), Os povos do Alto Xingu: história e cultura. Rio de Janeiro: EdUFRJ. pp. 21-62.
2005. The ecology of power: culture, place, and personhood in the Southern Amazon, A.D. 1000-2000. New York: Routledge.

HUGH-JONES, Christine. 1979. From the milk river: spatial and temporal processes in Northwest Amazonia. Cambridge: Cambridge University Press.

HUGH-JONES, Stephen. 1994. "Shamans, prophets, priests and pastors". In: C. Humphrey e N. Thomas (eds.), Shamanism, history and the state. Ann Arbor: University of Michigan Press. pp. 32-75.

. 1996. "Bonnes raisons ou mauvaise conscience? De l'ambivalence de certains amazoniens envers la consommation de viande". Terrains, 26:123148.

LADEIRA, Maria Inês. 1992. "O caminhar sob a luz": o território Mbyá à beira do oceano. Dissertação de Mestrado, Pontifícia Universidade Católica, São Paulo.

LARRICQ, Marcelo. 1993. Ipytuma, construcción de la persona entre los Mbya-Guaraní. Misiones: Editorial Universitaria, Universidad Nacional de Misiones.

LÉVI-STRAUSS, Claude. 1991. Histoire de lynx. Paris: Plon.

LOWREY, Kathleen Bolling. 2003. Enchanted ecology: magic, science and nature in the bolivian Chaco. $\mathrm{PhD}$ Thesis, University of Chicago.

MELIÀ, Bartolomeu. 1986. El guaraní conquistado y reducido: ensayos de etnohistoria. Asunción: Biblioteca Paraguaya de Antropología, vol. 5. 1990. "A Terra sem Mal dos Guarani". Revista de Antropologia, 33:3346.

. 2004. "La novedad Guarani (viejas cuestiones y nuevas preguntas). Revista bibliográfica (1987-2002)". Revista das Índias, 64:175-226 [volu- 
me monográfico: "La persistencia Guarani". Coordenação: Oscar Calavia Sáez].

MONTEIRO, John Manuel. 1992. "Os Guarani e a história do Brasil Meridional". In: M. Carneiro da Cunha (ed.), História dos índios no Brasil. São Paulo: FAPESP/Cia das Letras/SMC. pp. 475-498.

1999. "The crisis and transformation of invaded societies: coastal Brazil in the sixteenth century". In: F. Salomon and S. Schwartz (eds.), Cambridge history of the native peoples of the Americas, vol. III-1. Cambridge: Cambridge University Press. pp. 9731023.

MONTOYA, Pe. A. Ruiz de. 1876. Vocabulário y tesoro de la lengua guarani, ò mas bien tupi. Viena/Paris: Faesy y Frick/ Maisonneuve y Cia. 1985 [1639]. Conquista espiritual feita pelos religiosos da Companhia de Jesus nas províncias do Paraguai, Paraná, Uruguai e Tape. Porto Alegre: Martins.

MURA, Fábio. s.d.a Tese de doutorado em elaboração. Rio de Janeiro: PPGAS/ Museu Nacional.

s.d.b. "A trajetória histórica dos Chiru na construção da tradição de conhecimento kaiowá". Ms.

NECKER, Louis. 1979. Indiens guarani et chamanes franciscains: les premières réduction du Paraguay (1580-1800). Paris: Éditions Anthropos.

NIMUENDAJU, Curt U. 1946. The eastern Timbira. Berkeley: University of California Press. 1987. As lendas da criação e destruição do mundo como fundamentos da religião dos Apapocúva-Guarani. São Paulo: Hucitec.

NOELLI, Francisco. 1999. "Curt Nimuendajú e Alfred Métraux: a invenção da busca da 'terra sem mal'." Suplemento Antropológico, 34(2):123-166.
POMPA, Maria Cristina. 2000. "Per ripensar il 'profetismo' indigeno: I Tupinambá". Studi e Materiali di Storia delle Religioni, XXIV(1):145-200. 2003. Religião como tradução: missionários, Tupi e Tapuia no Brasil Meridional. São Paulo: Edusc/Anpocs.

RICOUER, Paul. 2000. La mémoire, l'histoire, l'oubli. Paris: Seuil.

RÍPODAS ARDANAZ, Daisy. 1987. "Movimientos shamánicos de liberación entre los Guaraníes (1545-1660)". Apartado de Teologia, XXIV(50):245-275.

RIVAL, Laura. 1998. "Preys at the center: resistence and marginality in Amazonia". In: S. Day, E. Papataxiarchis, and M. Stewart (eds.), Lilies of the field: marginal people who live for the Moment. Boulder: Westview. pp. 61-79. . 2002. Trekking through history: the Huarani of amazonian Ecuador. New York: Columbia University Press.

ROULET, Florencia. 1993. La resistencia de los Guaraní del Paraguay a la Conquista Española (1537-1556). Posadas: Editorial Universitária, Universidad Nacional de Misiones

SANTOS GRANERO, Fernando. 1991. The power of love. The moral use of knowledge amongst the Amuesha of Central Peru. London: The Athlone Press..

1993. "Templos e ferrarias: utopia e reinvenção cultural no Oriente Peruano". In: E. Viveiros de Castro \& M. Carneiro da Cunha (eds.), Amazônia: etnologia e história indígena. São Paulo: NHII/Fapesp. pp. 67-94.

. 1994. El poder del amor: poder, conocimiento y moralidade entre los Amuesha de la Selva Central del Perú. Quito: Abya-Yala.

. Ms. "Time is disease, suffering and oblivion: Yanesha historicity and the struggle against temporality". In: C. Fausto e M. Heckenberger (eds.), When time matters: history, memory and identity in indigenous Amazonia. 
SCHADEN, Egon. 1954a. "O estudo do índio brasileiro ontem e hoje". América Indígena, 14(3):233-252. . 1954b. "Aspectos fundamentais da cultura guarani". Boletim 188, Antropologia 4. São Paulo: Universidade de São Paulo.

. 1964. Aculturação indígena: ensaio sobre fatores e tendências da mudança cultural de tribos índias em contato com o mundo dos brancos. Tese de Cátedra, Universidade de São Paulo.

SEVERI, Carlo. 2000. "Cosmologia, crise e paradoxo: da imagem de homens e mulheres brancos na tradição xamânica kuna". Mana: Estudos de Antropologia Social, 6(1):121-155.

STECKLEY, John L. 1992. "The warrior and the lineage: jesuit use of iroquoian images to communicate christianity". Ethnohistory, 39(4):478-509.

SUSNIK, Branislava. 1965. El indio colonial del Paraguay: el Guarani colonial. vol. I. Asunción: Museo Etnográfico Andres Barbero. 1980. Los aborígenes del Paraguay: etnohistoria de los Guaranies (Epoca Colonial). vol. II. Asunción: Museo Etnográfico Andres Barbero.

THEVET, Fr. André. 1953 [1575]. "La cosmographie universelle". In: S. Lusagnet (ed.), Le Brésil et les brésiliens: les français en Amérique pendant la deuxième moitié du XVIe siécle. Paris: PUF.

VAINFAS, Ronaldo. 1995. A heresia dos índios: catolicismo e rebeldia no Brasil Colonial. São Paulo: Companhia das Letras.

VIVEIROS de CASTRO, Eduardo. 1992a. "O mármore e a murta: sobre a inconstância da alma selvagem". Revista de Antropologia, 35:21-74. .1992b. From the enemy's point of view: humanity and divinity in an amazonian society. Chicago: Chicago University Press.
WILDE, Guillermo. 2003a. Antropología historica del liderazgo Guarani misionero (1750-1850). PhD Thesis, Universidad de Buenos Aires. .2003b. "Poderes del ritual y rituales del poder: un análisis de las celebraciones en los pueblos jesuíticos de guaraníes". Revista Española de Antropología Americana, 33: 203-229.

WRIGHT, Robin. 1998. Cosmos, self and history in Baniwa religion: for those unborn. Austin: University of Texas Press.

1999. Transformando os deuses: os múltiplos sentidos da conversão entre os povos indígenas no Brasil. Campinas: FAPESP / Unicamp. 2004. Transformando os deuses: igrejas evangélicas, pentecostais e neopentecostais entre os povos indígenas no Brasil. Campinas: FAPESP / Unicamp.

WRIGHT, Robin \& HILL Jonathan. 1986. "History, ritual and myth: nineteenth century millenarian movements in the Northwest Amazon". Ethnohistory, 33(1):31-54. 
Resumo

Por meio de uma reanálise da literatura sobre a "religião guarani", pretende-se indicar como e em que direções ela se transformou, desde o século XVI, recriando-se como a "religião guarani" contemporânea, tal qual a descreveu a etnologia do século XX. O pano de fundo dessa análise é a leitura crítica da noção de um "modo de ser guarani" fundado em uma religiosidade impermeável à mudança. Busca-se sugerir que o contato com o cristianismo missionário e a experiência colonial conduziram a uma crescente negação do canibalismo enquanto fundamento do poder xamânico e da reprodução social, processo aqui denominado "desjaguarificação". Esse processo conduziu a mudanças na noção de pessoa e permitiu o surgimento de um novo modo de conceber a relação com animais e divindades, fundado agora em uma categoria nativa de amor.

Palavras-chave: Canibalismo, Religião, Missões, Colonialismo, Tupi-Guarani

\section{Abstract}

Launching a reanalysis of the literature concerning 'Guarani religion,' this article explores how and in which directions it has transformed since the $16^{\text {th }}$ century to eventually recreate itself as the contemporary 'Guarani religion' described by 20th century ethnology. The background to this analysis is a critical reading of the notion of a 'Guarani way of being' founded on a religiosity impervious to change. The article suggests that contact with Mission Christianity and the colonial experience led to the gradual negation of cannibalism as the basis of shamanic power and social reproduction - a process here termed 'dejaguarization.' This process led to changes in the Guarani notion of personhood and enabled the emergence of a new way of conceiving the human relationship to animals and divinities; a relationship henceforth founded on a native category of love.

Key words: Cannibalism, Religion, Missions, Colonialism, Tupi-Guarani 